\title{
3-Phosphoinositide-Dependent Protein Kinase 1
}

National Cancer Institute

\section{Source}

National Cancer Institute. 3-Phosphoinositide-Dependent Protein Kinase 1. NCI

Thesaurus. Code C30166.

3-phosphoinositide-dependent protein kinase 1 (556 aa, 63 kDa) is encoded by the human PDPK1 gene. This protein plays a role in signaling cascade activation. 